\title{
MEKANISME MAWAH SAPI DI DESA DAMAR CONDONG DALAM TINJAUAN KONSEP PEMBIAYAAN MUDHARABAH
}

Oleh :

\author{
Desi Septi Diana \\ Abd. Manaf \\ Muhammad Firdaus
}

\begin{abstract}
ABSTRAK
Praktik pembiayaan mudharabah dalam pengelolaan mawah sapi yang terjadi pada masyarakat Desa Damar Condong yakni modal yang diberikan oleh shahibul maal berupa barang (sapi). Kemudian sapi tersebut diberikan kepada mudharib. Mudharib bertanggung jawab atas perawatan sapi yang diberikan kepadanya tersebut. Hasil yang didapat dari pemeliharaan sapi dibagi rata yakni50:50. Namun ketika sapi tersebut hilang maka resiko sepenuhnya ditanggung oleh mudharib, shahibul maal bersikeras memberikan tanggung jawab tersebut tanpa terkecuali. Adapun rumusan masalah dalam penelitian ini adalah: 1 . Bagaimana Mekanisme Mawah Sapi di Desa Damar Condong ? 2. Bagaimana Mekanisme Mawah Sapi di Desa Damar Condong Dalam Tinjauan Konsep Pembiayaan Mudharabah? Tujuan Penelitian ini adalah:1.Untuk mengetahui Mekanisme Mawah Sapi di Desa Damar Condong. 2.Untuk mengetahui Mekanisme Mawah Sapi di Desa Damar Condong Dalam Tinjauan Konsep Pembiayaan Mudharabah. Riset ini ialah riset field research (riset lapangan) yang memakai pendekatan normatif- kualitatif. Prosedur normatif merupakan sesuatu riset yang memiliki obyek hukum, baik hukum selaku sesuatu ilmu ataupun aturanaturan yang sifatnya dogmatis ataupun hukum yang berkaitan dengan sikap serta kehidupan warga. Sebaliknya kualitatif digunakan selaku prosedur kajian riset guna menciptakan informasi deskriptif yang berbentuk perkata tertulis ataupun lisan dari orang- orang ataupun perilaku yang diamati secara langsung di lapangan. Hasil dari penelitian pembiayaan mudharabah mawah sapi yang dilakukan oleh masyarakat Desa Damar Condong tidak berjalan sebagaimana mestinya atau tidak sesuai dengan aturan pembiayaan mudharabah. Pertama modal yang diberikan berupa barang dikarenakan tidak adanya unsur percaya dan rela sepenuhnya ketika modal yang diberikan berupa uang tunai, yang kedua mudharib berkewajiban sepenuhnya ganti rugi apabila sapi yang dimawahkan kepadanya hilang, walaupun hilangnya sapi tersebut bukan kelalaian dari mudharib. kebijakan yang dibuat oleh shahibul maal di Desa Damar Condong ini juga melanggar fatwa DSN-MUI 07/DSNMUI/IV/2000 Tentang Pembiayaan Mudharabah yakni yang berkewajiban menanggung resiko ialah shahibul maal jika hilang nya barang tersebut bukan karena kelalaian mudharib.
\end{abstract}

\section{Kata Kunci : Pembiayaan Mudharabah, Mawah Sapi}

\section{PENDAHULUAN}

Alam ialah salah satu ciptaan Allah SWT yang sangat indah. Di dalamnya terdapat berbagai panorama alam indah yang bisa menenangkan jiwa serta indah jika dilihat oleh panca indera. Bermacam mahluk hidup yang terdapat di dalamnya yakni manusia, tanaman yang berbagai bentuk dan hewan sekalipun. Dalam bertahan hidup mahluk ciptaan Allah 
SWT selalu berdampingan memperoleh kebutuhan satu sama lain baik buat kebutuhan primer ataupun sekunder.

manusia membutuhkan tumbuhan dan hewan untuk sumber pangan dan pakaian. Tak hanya itu manusia juga menggunakan tumbuhan serta hewan untuk investasi. hewan juga termasuk investasi efektif yang dilakukan oleh masyarakat. Dimana mereka akan mendapatkan keuntungan dari perkembang biakan hewan yang mereka pelihara.

Hasil observasi dini yang penulis lakukan di Desa Damar Condong, penduduk lebih aktif berinvestasi dengan hewan ternak, baik hewan ternak berbentuk kambing ataupun sapi, sebab bagi warga desa Damar Condong hasil yang mereka peroleh dari perkembangbiakan hewan ternak tersebut banyak menguntungkan. Tetapi, tidak seluruh orang dapat dengan begitu gampang untuk memiliki seekor hewan ternak, karna harga yang relatif mahal dengan mata pencarian warga desa sebagaian besar ialah petani serta nelayan menutup kemungkin para warga desa Damar Condong buat memiliki hewan ternak. Sebagaimana perihal yang dilakukan oleh penduduk setempat dimana untuk memperoleh hewan ternak berbentuk sapi hingga sebagian orang lebih memilah mengelola sapi yang dimiliki oleh seseorang, sudah diketahui oleh orang banyak bahwa ketika pemilik sapi memberikan amanat kepada pengelola untuk menjaga sapi nya sehingga hasil dari keuntungan sapi tersebut hendak dipecah jadi dua kemudian dibagi dua yakni, untuk pemilik sapi serta pengelola. Disaat melakukan akad hal itu pula menjadi salah satu yang dibicarakan oleh warga desa Damar Condong ataupun antara pemilik sapi serta pengelolanya.

Berdasarkan hal ini maka seseorang yang tidak mempunyai materi yang cukup untuk membeli seekor sapi mempunyai cara lain untuk mendapatkan seekor sapi. Mereka hanya perlu merawat sapi milik pemodal baik dari segi pangan, perawatan dan perkembang biakan semua ditangung oleh pengelola kemudian mereka akan mendapatkan bagian 50\% keuntungan yang diperolah dari perkembangbiakan sapi tersebut. Namun, ada hal yang mengganjal ketika penulis melakukan observasi awal di Desa Damar Condong, Dimana saat sapi hilang maka sepenuhnya akan menjadi tanggung jawab pengelola. Pemilik sapi akan meminta kembali modal awal sepenuhnya dari pembelian sapi tersebut kepada pengelola. Pemilik sapi akan tetap meminta ganti rugi walaupun pengelola mengawah sapi tersebut dengan tanggung jawab sesuai dengan kesepakatan di awal akad dan tidak ada kelalaian di dalamnya. Hal ini tentu sangat membuat pengelola resah. Namun ini merupakan cara yang bisa meraka lakukan untuk mendapatkan hewan ternak, Walaupun pengelola merasa resah 
akan hal itu tetapi cara ini merupakan cara efektif yang bisa mereka tempuh untuk mendapatkan kehidupan yang lebih layak di masa yang akan datang. ${ }^{1}$

Mudharabah yakni sesuatu akad ataupun perjanjian antara dua orang ataupun lebih, dimana pihak kesatu memberikan modal usaha, sedangkan pihak kedua sediakan tenaga serta kemampuan, dengan syarat dibagi diantara mereka cocok dengan konvensi yang mereka tetapkan bersama. ${ }^{2}$

Pembiayaan mudharabah bagi Fatwa DSN Nomor. 07/ DSN- MUI/ IV/ 2000 merupakan akad kerjasama sesuatu usaha antara dua pihak dimana pihak kesatu sediakan segala modal, sebaliknya pihak kedua selaku pengelola, serta keuntungan usaha dibagi di antara mereka sesuai konvensi yang dituangkan dalam kontrak. ${ }^{3}$

Keuntungan dalam system mudharabah ini sebaiknya diketahui secara jelas serta ditegakkan presentase tertentu untuk pemilik modal serta pengelola modal yang sifatnya menyeluruh semacam, separuh, sepertiga, ataupun seperempat dan sejenisnya. Jika diresmikan beberapa keuntungan untuk salah satu pihak, sedangkan sisanya buat pihak yang lain, hingga itu merupakan usaha investasi yang tidak sah. Sebab dapat jadi keuntungan dari usaha itu hanyalah bagian, sehingga kerjasama itu wajib diberhentikan dalam keuntungannya. Lebih rusak lagi dari ini merupakan apabila shahibul maal menetapkan ketentuan presentasi tertentu dari modal yang tidak terpaut dengan usaha penanaman modal sebab itu berarti mengkompromikan antara usaha lewat system penanaman modal ini dengan usaha berbasis riba. $^{4}$

Fatwa DSN- MUI Nomor. 07/ DSN- MUI/ IV/ 2000 tentang pembiayaan mudharabah memutuskan Keuntungan mudharabah merupakan jumlah yang didapat sebagai kelebihan dari modal, bagian keuntungan seimbang untuk tiap pihak wajib diketahui dan dinyatakan pada waktu kontrak disepakati serta wajib dalam wujud presentasi (nisbah) dari keuntungan sesuai konvensi serta Penyedia dana menanggung seluruh kerugian akibat dari mudharabah, serta pengelola tidak boleh menanggung kerugian apapun kecuali disebabkan dari kesalahan disengaja, ataupun pelanggaran konvensi. ${ }^{5}$

\section{LANDASAN TEORI}

\footnotetext{
${ }^{1}$ Hasil observasi peneliti Di Desa Damar Condong Pada Tanggal: 23-26 Desember 2020

2 Akhmad Farroh Hasan, Fiqh Muamalah Dari Klasik Hingga Kontemporer (Teori dan Praktik), (Malang: UIN-Maliki Press, 2018), h. 105

${ }^{3}$ Sri Sudiarti, Fiqh Muamalah Kontemporer, (Medan: FEBI UIN-SU Press, 2018), h. 161

${ }^{4}$ Ibid., h. 170

${ }^{5}$ Fatwa DSN-MUI No.07/DSN-MUI/IV/2000 tentang pembiayaan mudharabah
} 
Mudharabah berasal dari kata Dharb, berarti memukul ataupun berjalan. Penafsiran memukul ataupun berjalan ini lebih tepatnya merupakan proses seseorang memukulkan kakinya dalam melaksanakan usaha. Secara bahasa (etimologi), mudharabah diambil dari kata الضرب فى الارضy yang maksudnya berpergian dimuka bumi ini buat berdagang. ${ }^{6}$

Secara terminologi, merujuk Fatwa DSN Nomor. 07/ DSN- MUI/ IV/ 2000 tentang Pembiayaan Mudharabah (Qiradh), mudharabah merupakan akad kerja sama sesuatu usaha antara 2 pihak dimana pihak awal (malik, shahibul maal, bank) sediakan segala modal, sedang pihak kedua ('amil, mudharib, nasabah) berperan sebagai pengelola, serta keuntungan usaha dibagi di antara mereka sesuai konvensi yang dituangkan dalam kontrak. Dalam literatur lain, Mudharabah merupakan Akad antara dua pihak dimana salah satu pihak memberikan kontribusi dana sepenuhnya (selaku modal) kepada pihak yang lain buat diperdagangkan/ diusahakan. Laba dibagi sama sebagimana yang teretera dalam konvensi. ${ }^{7}$

Berikut pengertian mudharabah menurut para Imam Mazhab:

1. Menurut Imam Hanafiyah Mudharabah ialah:

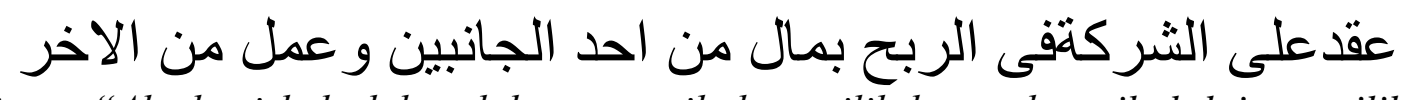

Artinya: "Akad syirkah dalam laba, satu pihak pemilik harta dan pihak lain pemilik jasa”

2. Menurut Imam Malikiyah Mudharabah ialah:

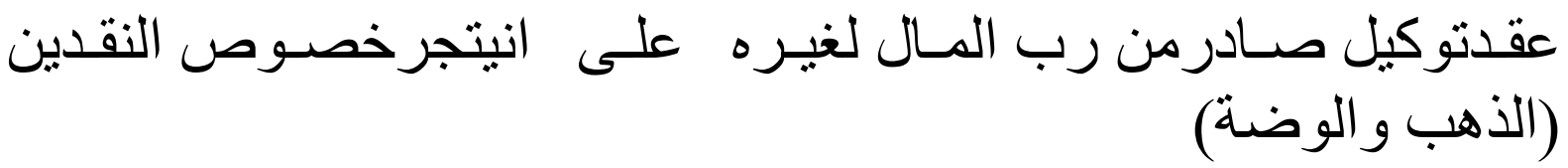

Artinya: "Akad perwakilan, di mana pemilik harta mengeluarkan hartanya kepada yang lain untuk diperdagangkan dengan pembayaran yang ditentukan (emas dan perak)"

3. Menurut Imam Hanabilah Mudharabah ialah:

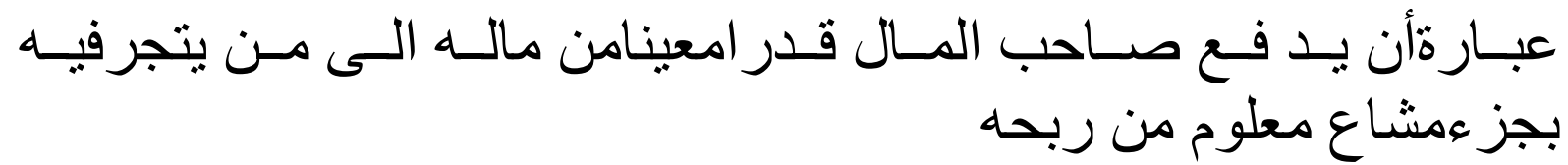

Artinya: "Ibarat pemilik harta menyerahkan hartanya dengan ukuran tertentu kepada orang yang berdagang dengan bagian dari keuntungan yang diketahui”.

4. Menurut Imam Syafi'iyah Mudharabah ialah:

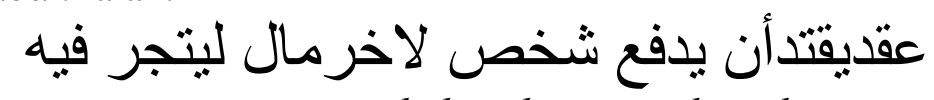

Artinya: "Akad yang menentukan seseorang menyerahakan hartanya kepada orang lain untuk ditijarahkan". ${ }^{\circ}$ 167.

${ }^{6}$ Sayyid sabiq, Fiqh Sunnah, jilid 4,Terj. Mujahidin Muhayan, (Jakarta: Pena Pundi Aksara, 2009), h.

${ }^{7}$ Fatwa DSN-MUI No.07/DSN-MUI/IV/2000 tentang pembiayaan mudharabah

${ }^{8}$ Sri Sudiarti, Fiqh Muamalah Kontemporer, (Medan: FEBI UIN-SU Press, 2018), h. 159-160 
Secara rinci Mudharabah merupakan sesuatu kontrak kemitraan (Partnership) yang berlandaskan pada prinsip pembagian hasil dengan metode pihak pertama yang menyerahkan modalnya kepada yang lain dimana modal tersebut dipergunakan untuk melaksanakan bisnis serta kedua belah pihak membagi keuntungan ataupun memikul beban kerugian bersumber pada isi perjanjian bersama. ${ }^{9}$

Dalam hal ini ulama fiqh sepakat bahwa mudharabah di dasari pada Firman Allah SWT surah Al-Baqarah ayat 198:

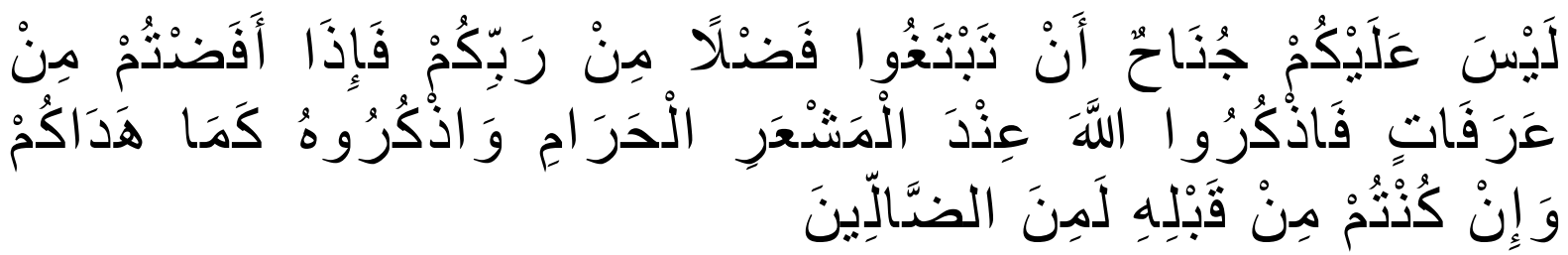

Artinya: Tidak ada dosa bagimu untuk mencari karunia (rezeki hasil perniagaan) dari Tuhanmu. Maka apabila kamu telah bertolak dari 'Arafat, berdzikirlah kepada Allah di Masy'arilharam. Dan berdzikirlah (dengan menyebut) Allah sebagaimana yang ditunjukkanNya kepadamu; dan sesungguhnya kamu sebelum itu benar-benar termasuk orang-orang yang sesat. ${ }^{10}$

Beberapa hadist tentang pembiayaan mudharabah:

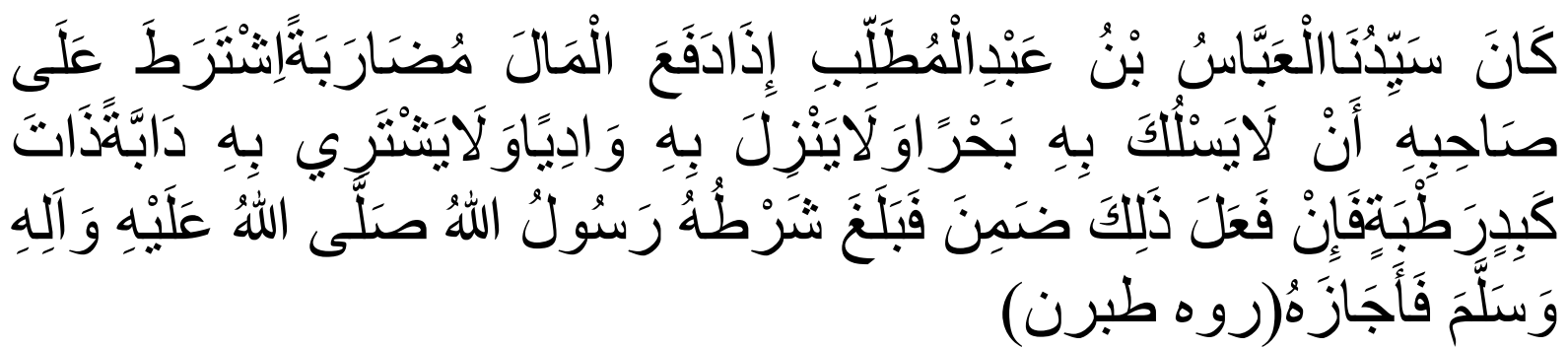

Artinya: "Dari Abbas bin Abdul Muthallib jika menyerahkan harta sebagai mudharabah, ia mensyaratkan kepada mudharibnya agar tidak mengurangi lautan dan tidak menuruni lembah, serta tidak membeli hewan ternak, jika persyaratan itu dilanggar, ia (mudharib) harus menanggung resikonya. Ketika persyaratan yang ditetapkan Abbas itu didengar Rasulullah membenarkannya. (HR. Thabrani)

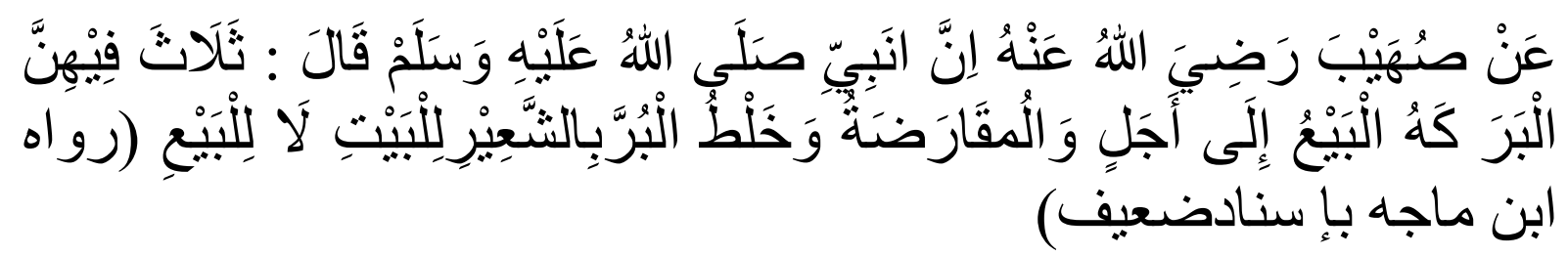

Artinya : "Dari Shuhaib r.a. bahwa Nabi SAW bersabda: ada tiga perkara yang di dalamnya terdapat keberkahan: jual beli tempo, muqadharah dan mencampur gandum dengan jagung untuk makanan di rumah bukan untuk dijual. (HR. Ibnu Majah dengan sanad (emah) $)^{11}$

\footnotetext{
${ }^{9}$ Afzalur rahman, Doktrin Ekonomi Islam, (Yogyakarta: Dana Bakti Wakaf, 1995), h.380

${ }^{10}$ Departemen Agama RI, Al-qur'an..., h. 32

${ }^{11}$ Ibid.,
} 
1. Fatwa Dewan Syari'ah Nasional No: 07/DSN-MUI/IV/2000 Tentang Pembiayaan Mudharabah (Qiradh)

Pertama : Ketentuan Pembiayaan:

a. Pembiayaan Mudharabah merupakan pembiayaan yang disalurkan oleh LKS kepada pihak lain buat sesuatu usaha yang produktif.

b. Dalam pembiayaan ini LKS selaku shahibul maal( pihak kesatu yang memberikan kontribusi berupa dana) membiayai $100 \%$ kebutuhan sesuatu proyek( usaha), sebaliknya pengusaha( nasabah) berperan selaku mudharib ataupun pengelola usaha.

c. Jumlah dana pembiayaan wajib dinyatakan dengan jelas dalam wujud tunai serta bukan piutang.

d. LKS selaku penyedia dana menanggung seluruh kerugian akibat dari mudharabah kecuali bila mudharib (nasabah) melaksanakan kesalahan yang disengaja, lalai, ataupun menyalahi perjanjian. Pada prinsipnya, dalam pembiayaan mudharabah tidak terdapat jaminan, tetapi supaya mudharib tidak melaksanakan penyimpangan, LKS bisa memohon jaminan dari mudharib ataupun pihak ketiga. Jaminan ini cuma bisa dicairkan apabila mudharib teruji melaksanakan pelanggaran terhadap hal- hal yang sudah disepakati bersama dalam akad.

e. Kriteria pengusaha, prosedur pembiayaan, serta mekanisme pembagian keuntungan diatur oleh LKS dengan mencermati fatwa DSN.

f. Bayaran operasional dibebankan kepada mudharib.

g. Dalam perihal penyandang dana( LKS) tidak melaksanakan kewajiban ataupun melaksanakan pelanggaran terhadap konvensi, mudharib berhak menemukan ubah rugi ataupun bayaran yang sudah dikeluarkan.

Kedua: Rukun serta Ketentuan Pembiayaan:

a. Penyedia dana (sahibul maal) serta pengelola (mudharib) wajib cakap hukum.

b. Modal yakni berbentuk uang tunai/ ataupun aset yang diberikan oleh penyedia dana kepada mudharib buat tujuan usaha dengan ketentuan selaku berikut:

1) Modal wajib dikenal jumlah serta jenisnya.

2) Modal dapat berupa uang maupun benda yang dapat dinilai. Bila modal diberikan dalam bentuk harta yang dimiliki, sehingga harta tersebut wajib dinilai pada waktu akad. 
3) Modal tidak bisa berupa piutang serta wajib dibayarkan kepada mudharib, baik secara bertahap ataupun tidak, sesuai dengan konvensi dalam akad.

d. Keuntungan mudharabah merupakan jumlah yang didapat selaku kelebihan dari modal. Ketentuan keuntungan berikut ini wajib dipadati:

1) Wajib diperuntukkan untuk kedua pihak serta tidak boleh disyaratkan cuma buat satu pihak.

2) Bagian keuntungan sama untuk tiap pihak wajib diketahui baik yang umum maupun khusus serta dinyatakan pada waktu kontrak disepakati serta wajib dalam wujud presentasi (nisbah) dari keuntungan yang sesuai dari hasil konvensi. Pergantian nisbah wajib bersumber dengan ketentuan yang sudah disepakati di awal.

3) Penyedia dana menanggung seluruh kerugian akibat dari mudharabah, serta pengelola tidak boleh menanggung kerugian apapun kecuali disebabkan dari kesalahan disengaja, kelalaian, ataupun pelanggaran konvensi.

e. Aktivitas usaha oleh pengelola (mudharib), selaku perimbangan (muqabil) modal yang disediakan oleh penyedia dana, wajib mencermati hal- hal berikut:

1) Pengelola tidak boleh menyalahi hukum syari'ah Islam dalam tindakannya yang berhubungan dengan mudharabah, serta wajib mematuhi kerutinan yang berlaku dalam kegiatan itu.

Ketiga : Sebagian Syarat Hukum Pembiayaan:

a. Mudharabah boleh dibatasi pada periode tertentu.

b. Kontrak tidak boleh berhubungan (mu'allaq) dengan suatu peristiwa di masa depan yang belum pasti terjalin.

c. Pada dasarnya, dalam mudharabah tidak terdapat ubah rugi, sebab pada dasarnya akad ini bertabiat amanah (yad al- amanah), kecuali akibat dari kesalahan disengaja, kelalaian, ataupun pelanggaran konvensi. ${ }^{12}$

Syarat-syarat dalam akad mudharabah ini ialah sebagai berikut:

1. Syarat 'Aqid

a. Sahibul maal serta mudharib hendaknya orang yang memiliki keahlian buat menyerahkan kuasa serta melakukan wakalah. 'Aqidain disyaratkan wajib cakap mengerjakan tasurruf.. ${ }^{13}$ (Qiradh)

${ }^{12}$ Fatwa Dewan Syari'ah Nasional No: 07/DSN-MUI/IV/2000 Tentang Pembiayaan Mudharabah 
2. Syarat yang berhubungan dengan modal.

a. Modal mestinya berbentuk uang tunai. Bilamana modal berupa benda, baik yang mobilitas ataupun tidak, berasal dari pendapat jumhur ulama mudharabah tidak sah. Para fuqaha pula tidak membolehkan modal mudharabah berupa benda. Namun, bilamana benda tersebut dijual serta uang hasil penjualannya digunakan sebagai modal mudharabah, bersumber pada pernyataan yang dikemukakan oleh Imam Abu Hanifah, Malik, serta Ahmad hukumnya dibolehkan. Sedangkan pernyataan yang dikemukaan oleh madzahab Syafi'i urusan tersebut senantiasa dibolehkan. ${ }^{14}$

b. Modal wajib jelas dan dikenal ukurannya.

c. Modal bukan dalam berupa utang.

d. Modal diserahkan oleh mudharib karna modal merupakan amanah yang wajib terletak ditangan mudharib buat digunakan selaku usaha.. ${ }^{15}$

3. Syarat Keuntungan

a. Keuntungan mestinya dikenal kadarnya:

b. Keuntungan dipunyai bersama dimana pembagian secara persentase semacam: $30 \%$ : 70\%, 50\%: 60\% serta sebagainya. Bilamana keuntungan dipecah dengan syarat yang tidak legal dalam Mudharabah ${ }^{16}$

Akad mudharabah mempunyai berbagai macam rukun yang sudah ditentukan oleh ulama guna memastikan sahnya akad tersebut, namun para ulama berbeda pandangan tentang rukun mudharabah merupakan ijab serta qabul ialah lafadz yang menampilkan ijab serta qabul dengan memakai mudharabah, muqaridhah, muamalah, ataupun kata yang searti dengannya.

a. Pelaku (pemodal ataupun pengelola). Pelaku dalam akad mudharabah bisa terdiri dari sebagian pelaksana. Pihak awal berperan selaku pemodal (shahibul al- maal), lagi pihak kedua berperan selaku pelaksana usaha (mudharib), tanpa dua pelaku ini hingga akad mudharabah tidak hendak terdapat.

b. Obyek mudharabah (modal serta kerja). Aspek kedua obyek mudharabah yang ialah konsekuensi logis dari kegiatan yang dicoba oleh para pelaksana. pemodal

${ }^{13}$ Ahmad Wardhi Muslihc, Fiqih Muamalah, ( Jakarata: Amzah, 2010), h. 373

${ }^{14}$ Akhmad Farroh Hasan, Fiqh Muamalah Dari Klasik Hingga Kontemporer (Teori dan Praktik), ..., h. 109

15 Mahmudatus Sa'diyah,Mudharabah Dalam Fiqih Dan Perbankan Syari'ah,Volume 1, No.2, Desember 2013, h.311

${ }^{16}$ Ahmad Wardhi Muslihc, Fiqih Muamalah,..., h. 374 
menyerahkan modalnya selaku obyek mudharabah, lagi pelaksana usaha menyerahkan kerjanya (keahliannya) selaku obyek mudharabah. ${ }^{17}$

c. Ijab serta qabul ialah persetujuan kedua belah pihak, ialah konsekuensi dari prinsip antaradhin minkum (bersama rela). Disini kedua belah pihak secara rela bersepakat buat mengikatkan diri dalam akad mudharabah. Pihak yang memiliki dana sepakat dengan kedudukannya sebagai pihak yang mengkontribusikan dana, sedangkan pelaksana usaha sepakat dengan kedudukannya yakni mengkontribusikan kerja. Ada pula Ketentuan ijab serta qabul merupakan:

1) Ijab serta qabul itu wajib jelas menampilkan iktikad buat melaksanakan aktivitas mudharabah.

2) Ijab serta Qabul wajib berjumpa.

3) Ijab serta Qabul wajib serupa dengan tujuan pihak kesatu sesuai dengan kemauan pihak kedua. $^{18}$

d. Nisbah (keuntungan). Mudharib memperoleh imbalan atas kerjanya, sebaliknya shahibul maal menerima imbalan atas penyertaan modalnya. Nisbah inilah yang menghindari akan terjadinya perselisihan antara kedua belah pihak menimpa metode pembagian keuntungan. ${ }^{19}$

Mudharabah dibagi menjadi dua :

\section{Mudharabah Mutlaqah}

Mudharabah mutlaqah ialah penyerahan modal tanpa ketentuan. Pengusaha ataupun mudharib leluasa mengelola modal itu dengan usaha apa saja yang baginya bakal mendatangkan keuntungan serta di wilayah mana saja yang mereka mau.. ${ }^{20}$

\section{Mudharabah Muqayyadah}

Mudharabah Muqayyadah dituturkan pula Restriced Mudharabah merupakan Mudharib dibatasi dengan batas tipe usaha, waktu serta tempat usaha. Dengan terdapatnya pembatasan ini kerapkali mencerminkan kecendrungan universal shahibul maal dalam merambah dunia usaha. $^{21}$

Menurut Asmuni Mth dalam tulisannya, ganti rugi (Dhaman) perspektif hukum islam, bahwa teori ganti rugi itu “ ide ganti rugi terhadap perdata maupun pidana. Sejak awal sudah

17 Adiwarman A. Karim, Bank Islam Analisis Fiqh dan Keuangan, (Jakarta: Raja Grafindo Perdasa, 2004), h. 182

${ }^{18}$ Mahmudatus Sa'diyah,Mudharabah Dalam Fiqih Dan Perbankan Syari'ah,..., h.310

${ }^{19}$ Veithzal Rivai, Islamic Financial Manajgement, (Jakarta: PT. Raja Grafindo Persada, 2008), h. 126

${ }^{20}$ Mansur, Seluk Beluk Ekonomi Islam, (Salatiga: STAIN Salatiga Press, 2009), h. 83.

${ }^{21}$ Muhammad Syafi'i Antonio, Bank Syariah Dari Teori Ke Praktek, ..., h. 97 
disebutkan oleh nash alquran maupun hadist Nabi. Dari nash-nash tersebut para ulama merumuskan berbagai kaidah fiqh yang berhubungan dengan dhaman atau ganti rugi. Memang diakui sejak awal, para fuqaha tidak menggunakan istilah masuliyah madaniyah sebagai sebutan tanggungan perdata, dan juga masuliyah al-jina'yah untuk sebutan tanggung jawab pidana..

Ganti rugi (ta'wid) hanya boleh dikenakan atas pihak yang dengan sengaja atau karena kelalaian melakukan sesuatu yang menyimpang dari ketentuan akad dan menimbulkan kerugian pada pihak lain. Besar ganti rugi (ta'wid) adalah sesuai dengan kerugian yang rill (real loss) yang pastidialami (fixed cost) dalam transaksi tersebut dan bukan kerugian yang diperkirakan akan terjadi (potentional loss) karena adanya peluang yang hilang (opportunity loss atau al-furshah al-dhai'ah). Ganti rugi ta'wid hanya boleh digunakan pada transaksi (akad) yang menimbulkan utang piutang (dain), seperti salam, istishna', Ijarah dan Mudharabah. $^{22}$

Salah satu pembahasan yang terkait dengan pembiayaan mudharabah ialah sistem bagi hasil. Bagi hasil merupakan syarat utama dalam akad mudharabah. Apabila hendak melakukan perjanjian mudharabah maka bagi hasil merupakan pembahasan yang amat penting yakni tentang pembagian hasil jika usaha itu berhasil atau untung dan ketentuan penanggungan kerugian. Jika usaha yang dijalankan dalam pembiayaan mudharabah itu bangkrut maka pemabgian keuntungan yang berlaku dari tiap-tiap kontrak usaha yang dibuat berbeda antara satu kontrak dengan lainnya. Walaupun berbeda namun tidak terlepas dari asas kesepakatan bersama dan tidak saling mendzalimi.

Jika kontrak kerja yang dibuat itu berupa murni (pihak yang berkongsi sama-sama memberikan modal dan sama-sama mengolahnya) maka nisbah keuntungan kedua pihak adalah ditentukan dari besar modal yang diberikan. Jika besaran modal yang diberikan sama maka pembagian hasil keuntungan adalah sama. Namun jika salah satu pihak lebih banyak memberikan tenaganya dalam usaha tersebut maka diperbolehkan nisbah keuntungan tersebut lebih besar dari yang sedikit tenaganya. Inilah keadilan yang diinginkan oleh Islam.

Sedangkan kerugian yang terjadi, maka dibagi menurut besarnya modal yang diberikan, pihak yang menyetor modal lebih besar akan menanngung presentase kerugian lebi besar pula dan pihak pemodal lebih kecil akan menanggung presentase yang lebih sedikit. Jadi jika ada suatu akad kerjasama yang salah satu pihak tidak mau menanggung kerugian maka akad

22 A. Rahmad Asmuni, Ilmu Fiqh 3, (Jakarta: Direktorat pemberdayaan wakaf Direktorat Jendral bimbingan masyarakat islam,2007), h.120-123 
seperti itu tidak sah menurut syara'. Begitu pula jika sebuah akad kerjasama yang mensyaratkan bahwa keuntungan hanya untuk salah satu pihak saja. ${ }^{23}$

Menurut al-Mawardi dalam al-Hawi al-Kabir bahwa bagi pihak yang memiliki modal lebih pembiayaan mudharabah maka akan mendapat keuntungan yang lebih banyak. Demikian pula jika mengalami kebangkrutan maka pihak pemodal yang lebih besar akan menanggung kerugian yang lebih banyak pula.besar kecilnya nisbah keuntungan adalah tergantung dari bentuk kongsi yang disepakati. Dalam mudharabah besarnya nisbah keuntungan diukur dari tenaga yang dikeluarkan atau juga besarnya nisbah itu bisa diukur dari tenaga dan modal yang dikeluarkan. ${ }^{24}$

\section{METODE PENELITIAN}

Riset ini ialah riset field research (riset lapangan) yang memakai pendekatan normatifkualitatif. Prosedur normatif merupakan sesuatu riset yang memiliki obyek hukum, baik hukum selaku sesuatu ilmu ataupun aturan- aturan yang sifatnya dogmatis ataupun hukum yang berkaitan dengan sikap serta kehidupan warga. ${ }^{25}$ Sebaliknya kualitatif digunakan selaku prosedur kajian riset guna menciptakan informasi deskriptif yang berbentuk perkata tertulis ataupun lisan dari orang- orang ataupun perilaku yang diamati secara langsung di lapangan. ${ }^{26}$

Pendekatan riset ini digunakan sebagai pendekatan yang dapat memperkenalkan mekanisme mawah sapi di desa Damar Condong dalam tinjauan konsep pembiayaan mudharabah.

Pada riset ini dapat kita ketahui bahwa ada dua sumber informasi, ialah sumber data primer serta sumber data sekunder..

\section{Data Primer}

Sumber data primer merupakan sumber informasi yang diambil dari sumber awal yang terdapat di lapangan. ${ }^{27}$ Sumber informasi yang jadi sumber data primer dalam riset ini merupakan warga Desa Damar Condong yang melaksanakan mawah sapi.

\section{Data Sekunder}

Sumber data Sekunder merupakan Sumber informasi yang diperoleh dari sumber kedua sehabis sumber data primer. ${ }^{28}$ Data sekunder riset ini peroleh dari pustaka, baik yang

\footnotetext{
23 Afjalur Rahman, Doktrin Ekonomi Islam,(Yogyakarta: Dhana Bakti Prima Yasa, 2002), h. 39-55

${ }^{24}$ Al-Mawardi, al-Hawi al-Kabir, (Beirut: Darr al Fikr,tth), h.159

${ }^{25}$ Soerjono Soekanto \& Sri Mamudji, Penelitian Hukum Normative Suatu Tinjauan Singkat, (Jakarta: Raja Grfindo Persada, 1985), h. 1

${ }^{26}$ Lexy J. Moelong, Metodologi Penelitian Kualitatif, (Bandung: PT. Remaja Rosdakaya, 2008), h. 4

27 Burhan Bungin, Metodologi Penelitian Sosial: Fromat 2 Kuantitatif dan Kualitatif, (Surabaya: Airlangga University Press, 2005), h. 128.

${ }^{28}$ Ibid., h. 128
} 
berbentuk novel, harian, serta lain sebagainya yang terpaut dengan riset yang diaplikasikan oleh penulis

Adapun teknik pengumpulan data yang digunakan oleh peneliti dalam melakukan penelitian ini adalah teknik

Observasi ataupun pengamatan merupakan aktivitas keseharian manusia dengan memanfaatkan panca indra mata selaku alat bantu utamanya tidak hanya panca indra berupa mata ada juga panca indera seperti: kuping, penciuman, mulut serta kulit

Wawancara ialah salah satu metode pengumpulan informasi yang dicoba dengan proses tanya jawab oleh pewawancara dengan informan ataupun orang yang diwawancarai secara tatap muka yang berlangsung satu arah. ${ }^{29}$ Dalam perihal ini penulis melaksanakan wawancara langsung dengan 10 orang warga di Desa Damar Condong.

Dokumentasi diperuntukan buat mendapatkan informasi langsung dari tempat riset meliputi: buku- buku yang rilevan, peraturan- peraturan, laporan aktivitas, potret- potret, film dokumenter informasi yang rilevan riset.

Sesudah informasi dianalisis maka, dalam riset ini dibutuhkan kebenaran untuk mendapatkan keabsahan penemuan dengan memanfaatkan suatu pengecek: ${ }^{30}$

Presistent Observation( Kesungguhan Pengamatan) ialah mengadakan observasi secara selalu terhadap objek riset guna menguasai indikasi lebih mendalam terhadap bermacam kegiatan yang lagi berlangsung dilokasi riset, Triangulasi ialah metode pemeriksa keabsahan informasi yang menggunakan suatu yang lain diluar untuk keperluan pengecekan keabsahan informasi ataupun pembanding terhadap informasi itu dan Peerdering (Pengecekan sejawat lewat dialog) ialah metode yang dicoba dengan metode mengekspos hasil sementara ataupun hasil akhir diperoleh dalam wujud dialog analisis dengan rekan- rekan sejawat.

Metode penyusunan pada riset ini penulis menggunakan ketentuan penulisan yang ada di dalam buku pedoman penyusunan skripsi yang disusun oleh Team Fakultas Syariah Institut Agama Islam Negara( IAIN) Langsa Tahun 2020

\section{HASIL PENELITIAN DAN PEMBAHASAN}

Desa Damar Condong memiliki satu sejarah mengapa dinamakan damar Condong, menurut sesepuh Desa Damar Condong, yakni Bapak Harun.S dan Bapak sutarno Wijaya memaparkan bahwasanya Damar Condong pada awalnya adalah kampong Damar Condong.

\footnotetext{
${ }^{29}$ Burhan Bungin, Penelitian Kualitatif (Jakarta: Kencana, 2007), h. 108.

${ }^{30}$ Lexy J. Moleong, Metode Peneitian Kualitatif, (Bandung: Remaja Rosdakarya, 2007), h. 172
} 
Damar Condong adalah sebuah nama yang diambil dari sebuah pohon damar yang masa lalu pohon damar tersebut condong ke sungai Air Masin, sungai yang menjadi batas Desa Damar Condong dengan Provinsi Aceh. Pada saat itu pohon Damar yang condong tersebut dipergunakan masyarakat sebagai jembatan untuk menyebrang ke Provinsi Aceh.

Desa Damar condong terdiri dari 6 wilayah dusun, Desa Damar Condong adalah Desa yang berada di wilayah Kecamatan Pematang Jaya Kabupaten Langkat, salah satu Desa dari 8 Desa yang berada di kecamatan Pematang Jaya yang terletak kurang lebih $111 \mathrm{Km}$ dari Kabupaten Langkat, kurang lebih $8 \mathrm{Km}$ kearah selatan ibukota Kecamatan. 4 dusun berada dalam satu hamparan, sedangkan 2 Dusun lagi terpisah dengan Perkebunan PT H. Sulaiman Saleh yang berjarak 2,5 Km dari ibu Kota Pemerintahan Desa Damar Condong.

Berdasarkan dari hasil wawancara yang penulis lakukan di Desa Damar Condong dengan masyarakat desa bahwa praktik mawah sapi yang dilakukan oleh masyarakat desa Damar Condong dijalankan sesuai dengan keuntungan yang bisa didapatkan oleh kedua belah pihak dimana mudharib dalam menjalankan perannya sebagai pengelola bermodalkan keberanian untuk mengawah sapi milik shahibul maal. Selain itu, mudharib juga dibebankan untuk mengganti kerugian

Praktiknya masyarakat enggan untuk memberikan modal berupa uang tunai melainkan berupa barang dimana juga tidak dijelaskan harga spesifik barang yang diberikan kepada mudharib, dari hasil penelitian yang penulis lakukan hal ini disebabkan terdapat unsur ketidak percayaan shahibul maal kepada mudharib dalam mengelola modal yang nantinya akan diberikan kepada mudharib. Sehingga shahibul maal memutusan untuk memberikan modal berupa sapi bukan dengan uang. Padahal salah satu syarat pembiayaan mudharabah ialah memberikan modal berupa uang tunai dan jika modal berupa barang maka boleh dijadikan modal dengan ketentuan barang tersebut harus dinilai harganya atau boleh dijual terlebih dahulu barulah uang hasil penjualan tersebut digunakan untuk modal.

Ijab serta qabul ialah persetujuan kedua belah pihak, ialah konsekuensi dari prinsip antaradhin minkum (bersama-sama rela). Disini kedua belah pihak secara rela bersepakat buat mengikatkan diri dalam akad mudharabah. Pihak yang memiliki dana sepakat dengan kedudukannya sebagai pihak yang mengkontribusikan dana, sedangkan pelaksana usaha sepakat dengan kedudukannya yakni mengkontribusikan kerja. ${ }^{31}$

Ijab dan qabul merupakan hal terpenting yang harus dilakukan oleh shahibul maal dan mudharib. Dimana pada saat kedua belah pihak telah melakukan ijab dan qabul maka berarti

\footnotetext{
${ }^{31}$ Mahmudatus Sa'diyah,Mudharabah Dalam Fiqih Dan Perbankan Syari'ah,..., h.310
} 
keduanya sudah bersepakat untuk saling rela. Namun, pada mekanisme mawah sapi yang dilakukan oleh masyarakat desa Damar Condong shahibul maal enggan untuk memberikan modal berupa uang tunai kepada mudharib. Dari hasil wawancara yang penulis dapat bahwa shahibul maal tidak merelakan jika modal yang diberikan berupa uang tunai arena ditakutkan modal tersebut tidak dikelola dengan baik. Dalam hal ini maka praktik mawah sapi di desa Damar Condong tidak sesuai dengan salah satu rukun yakni Ijab dan qabul karna salah satu pihak tidak merelakan sepenuhnya sapi modal tersebut dikelola oleh mudharib.

Mudharabah Muqayyada dituturkan pula Restriced Mudharabah merupakan Mudharib dibatasi dengan batas tipe usaha, waktu serta tempat usaha. Dengan terdapatnya pembatasan ini kerapkali mencerminkan kecendrungan universal shahibul maal dalam merambah dunia usaha. $^{32}$

Mudharabah muqayyadah On Balance Sheet( investasi terikat) ialah pemodal yang memberikan konribusi dana (shahibul maal) memberikan ketentuan yang diajukan oleh pemilik modal kepada mudharib dalam penglolaan dana serupa misalnya hanya melaksanakan mudharabah bidang tertentu, metode, waktu serta tempat tertentu saja. ${ }^{33}$

Praktik mawah sapi yang dilakukan oleh masyarakat desa Damar Condong termasuk kedalam pembiayaan mudharabah muqayyadah dikarenakan modal yang diberikan oleh shahibul maal harus digunakan untuk praktik mawah sapi. Lebih tepatnya termasuk kedalam Mudharabah muqayyadah On Balance Sheet. namun dimana yang seharusnya diberikan oleh shahibul maal berupa modal yang kemudian akan dikelola oleh mudharib, tetapi shahibul maal memberikan modal berbentuk barang. Untuk itu maka pembiayaan mudharabah yang dilakukan masyarakat desa Damar Condong merupakan Mudharabah muqayyadah On Balance Sheet namun tidak dijalankan sebagaimana ketentuan yang berlaku dalam pembiayaan Mudharabah muqayyadah On Balance Sheet.

Ganti rugi ( $t a$ 'wid) hanya boleh dikenakan atas pihak yang dengan sengaja atau karena kelalaian melakukan sesuatu yang menyimpang dari ketentuan akad dan menimbulkan kerugian pada pihak lain.. ${ }^{34}$ Salah satu pembahasan yang terkait dengan pembiayaan mudharabah ialah sistem bagi hasil. Bagi hasil merupakan syarat utama dalam akad mudharabah. Apabila hendak melakukan perjanjian mudharabah maka bagi hasil merupakan pembahasan yang amat penting yakni tentang pembagian hasil jika usaha itu berhasil atau untung dan ketentuan penanggungan kerugian. Jika usaha yang dijalankan dalam pembiayaan

\footnotetext{
${ }^{32}$ Muhammad Syafi'i Antonio, Bank Syariah Dari Teori Ke Praktek, ..., h. 97

${ }^{33}$ Adiwarman A. Karim, Bank Islam Analisis Fiqh dan Keuangan, ..., h.188

${ }^{34}$ A. Rahmad Asmuni, Ilmu Fiqh 3,..., h.120-123
} 
mudharabah itu bangkrut maka pembagian keuntungan yang berlaku dari tiap-tiap kontrak usaha yang dibuat berbeda antara satu kontrak dengan lainnya. Walaupun berbeda namun tidak terlepas dari asas kesepakatan bersama dan tidak saling mendzalimi.

Jika kontrak kerja yang dibuat itu berupa murni (pihak yang berkongsi sama-sama memberikan modal dan sama-sama mengolahnya) maka nisbah keuntungan kedua pihak adalah ditentukan dari besar modal yang diberikan. Jika besaran modal yang diberikan sama maka pembagian hasil keuntungan adalah sama. Namun jika salah satu pihak lebih banyak memberikan tenaganya dalam usaha tersebut maka diperbolehkan nisbah keuntungan tersebut lebih besar dari yang sedikit tenaganya. Inilah keadilan yang diinginkan oleh Islam.

Sedangkan kerugian yang terjadi, maka dibagi menurut besarnya modal yang diberikan, pihak yang menyetor modal lebih besar akan menanngung presentase kerugian lebi besar pula dan pihak pemodal lebih kecil akan menanggung presentase yang lebih sedikit. Jadi jika ada suatu akad kerjasama yang salah satu pihak tidak mau menanggung kerugian maka akad seperti itu tidak sah menurut syara'. Begitu pula jika sebuah akad kerjasama yang mensyaratkan bahwa keuntungan hanya untuk salah satu pihak saja. ${ }^{35}$

Menurut al-Mawardi dalam al-Hawi al-Kabir bahwa bagi pihak yang memiliki modal lebih pembiayaan mudharabah maka akan mendapat keuntungan yang lebih banyak. Demikian pula jika mengalami kebangkrutan maka pihak pemodal yang lebih besar akan menanggung kerugian yang lebih banyak pula.besar kecilnya nisbah keuntungan adalah tergantung dari bentuk kongsi yang disepakati. Dalam mudharabah besarnya nisbah keuntungan diukur dari tenaga yang dikeluarkan atau juga besarnya nisbah itu bisa diukur dari tenaga dan modal yang dikeluarkan. ${ }^{36}$

Fatwa Dewan Syari'ah Nasional No: 07/DSN-MUI/IV/2000 Tentang Pembiayaan Mudharabah (Qiradh) mengenai keuntungan mudharabah adalah jumlah yang didapat sebagai kelebihan dari modal. Salah satu syarat keuntungan yakni Penyedia dana menanggung semua kerugian akibat dari mudharabah, dan pengelola tidak boleh menanggung kerugian apapun kecuali diakibatkan dari kesalahan disengaja, kelalaian, atau pelanggaran kesepakatan. ${ }^{37}$

Praktik mawah sapi merupakan kegiatan yang sudah lumrah dilakukan oleh masyarakat desa Damar Condong. Bagaimana tidak, dari hasil mawah sapi masyarakat bisa

35 Afjalur Rahman, Doktrin Ekonomi Islam,..., h. 39-55

${ }^{36}$ Al-Mawardi, al-Hawi al-Kabir,..., h.159 (Qiradh)

37 Fatwa Dewan Syari'ah Nasional No: 07/DSN-MUI/IV/2000 Tentang Pembiayaan Mudharabah 
meningkatkan kondisi ekonomi mereka dan bisa menabung untuk di masa yang akan datang dari hasil perkembangbiakan sapi tersebut. Mudharib berkewajiban untuk merawat sapi dengan sebagimana yang disepakati waktu akad mudharabah berlangsung. Namun tentunya setiap usaha dan kerja keras merupakan suatu usaha yang bisa mendapatkan keuntungan kecil maupun besar, begitu juga dalam konteks kerugian tidak selalu usaha yang dilakukan itu menguntungkan bisa saja mengalami kerugian. Pada praktiknya yang terjadi di desa Damar Condong apabila mudharib kehilangan sapi yang dimawahkan kepadanya baik hilang karena kelalaian nya maupun bukan kelalaian mudharib atau dengan kata lain mudharib telah merawatnya dengan sungguh-sungguh tidak terdapat kelalaian didalamnya, maka shahibul maal akan tetap meminta ganti rugi sesuai dengan harga sapi yang hilang tersebut. Walaupun sapi tersebut sudah menghasilkan beberapa keturunan. Namun shahibul maal tetap meminta ganti rugi sesuai dengan harga modal yang mereka keluarkan pada saat akad mudharabah berlangsung. praktik ganti rugi yang dilakukan oleh kedua belah pihak tidak sesuai dengan fatwa DSN-MUI 07/DSN-MUI/IV/2000 Tentang Pembiayaan Mudharabah (Qiradh) bahwa yang berkewajiban menangung resiko atau kerugian yang terjadi pada pembiayaan mudharabah jika mudharib tidak lalai dan bukan karena kesengajaan mudharib ialah shahibul maal. bahkan shahibul maal tidak menerima alasan apapun dan tetap mewajibkan mudharib mengganti rugi sesuai dengan modal awal yang diberikan.

Dari penjelasan diatas penulis menyimpulkan bahwa ketika akad pembiayaan mudharabah berlangsung maka artinya kedua belah pihak telah setuju untuk saling mengikat diri dan saling mempercayakan apa yang telah disepakati, sebagaimana yang tertera di dalam rukun ijab dan qabul bahwa antara kedua belah pihak harus saling sama-sama rela, begitu juga hal nya dengan kerugian yang terjadi pada saat pembiayaan mudharabah berlangsung maka penyedia dana berkewajiban untuk menanggung segala kerugian yang terjadi, kecuali jika kerugian tersebut dikarenakan kelalaian atau kesengajaan dari mudharib. Berbeda dengan yang dilakukan oleh masyarakat desa Damar Condong bahwa masyarakat enggan untuk memberikan modal berupa uang tunai melainkan dengan barang hal ini disebabkan karna ketidakpercayaan salah satu pihak terhadap modal yang ia berikan kepada mudharib, shahibul maal juga meminta ganti rugi sesuai dengan modal awal walaupun sapi tersebut sudah memberikan keturunan. Bahkan tidak meninjau kembali apakah sapi tersebut hilang karena kelalaian atau tidak disengaja.

Dari analisis yang sudah penulis bahas sebelumnya mekansme mawah sapi yang terjadi pada masyarakat desa Damar Condong tidak sesuai dengan teori pembiayaan mudharabah 
maupun dalam fatwa DSN-MUI 07/DSN-MUI/IV/2000 Tentang Pembiayaan Mudharabah (Qiradh), untuk itu penulis merasa perlunya hal ini untuk ditinjau kembali supaya berjalan sesuai dengan teori pembiayaan mudharabah agar tidak menimbulkan kemudharatan pada saat pembiayaan mudharabah ini dilaksanakan kembali oleh masyarakat desa Damar Condong. Seperti yang kita ketahui bahwa pembiayaan mudharabah salah satu syarat mudharabah ialah modal harus berupa uang tunai bukan berupa barang karena ditakutkan adanya unsur penipuan dan salah satu rukun ialah ijab dan qabul yakni saling sama-sama rela, maknya kedua belah pihak harus bersama membangun kepercayaan dan menyerahkan kontribusi dana dan kerja untuk perjanjian kerjasama yang telah disepakati, dan shahibul maal sebagai penyedia dana menangung resiko terhadap kerugian yang terjadi pada pembiayaan mudharabah, namun pada praktiknya masyarakat memberikan modal berupa barang dan bukan uang tunai karena ditakutkan akan terjadi ketidakjelasan terhadap dana yang akan dielola oleh mudharib. Serta mudharib harus menanggung seluruh kerugian yang terjadi. Mekanisme yang dilakukan oleh masyarakat desa Damar Condong ini memberatkan salah satu pihak, dimana seharusnya mekanisme mawah sapi ini tidak dilakukan lagi karna sangat beresiko untuk mudharib jika mekanisme nya tidak dijalankan sesuai dengan teori pembiayaan mudharabah.

Praktik mawah sapi yang dilakukan oleh masyarakat desa Damar Condong dalam konteksnya yakni masyarakat yang berlaku sebagai pihak shahibul maal tidak pernah memberikan modal berupa uang tunai melainkan barang berupa sapi. Dari hasil wawancara yang penulis lakukan terdapat unsur ketidakpercaya antara salah satu pihak. Setelah sapi tersebut diberikan kepada mudharib maka mudharib akan sepenuhnya merawat sapi tersebut hingga berkembang biak. Namun, dalam hal ini apabila dalam pelaksanaan praktik mawah ini sedang berlangsung dan sapi tersebut hilang ditangan mudharib baik mudharib lalai atau tidak dalam merawat nya maka shahibul maal mewajibkan untuk mudharib menggantikan sepenuhnya sapi yang hilang tersebut sesuai dengan jumlah harga pembelian sapi pada saat awal kerjasama antara kedua belah piak terjadi atau yang disebut juga modal awal.

Modal mestinya berbentuk uang tunai. Bilamana modal berupa benda, baik yang mobilitas ataupun tidak, berasal dari pendapat jumhur ulama mudharabah tidak sah. Para fuqaha pula tidak membolehkan modal mudharabah berupa benda. Modal wajib berupa duit tunai sebab benda tidak bisa ditentukan taksiran biayanya serta menyebabkan ketidakpastian (gharar) besarnya modal mudharabah. Bilamana modal mudharabah berupa benda ditakutkan akan terdapat faktor penipuan, sebab dengan demikian keuntungan jadi tidak jelas saat akan 
dibagi, serta ini akan jadi perdebatan diantara kedua belah pihak. Namun, bilamana benda tersebut dijual serta uang hasil penjualannya digunakan sebagai modal mudharabah, bersumber pada pernyataan yang dikemukakan oleh Imam Abu Hanifah, Malik, serta Ahmad hukumnya dibolehkan. Sedangkan pernyataan yang dikemukaan oleh madzahab Syafi'i urusan tersebut senantiasa dibolehkan. ${ }^{38}$

Praktik mawah sapi yang dilakukan oleh masyarakat desa Damar Condong tidak sesuai dengan salah satu syarat dari pembiayaan mudharabah dimana dalam

\section{PENUTUP}

Kesimpulan

1. Mekanisme mawah sapi yang terjadi pada masyarakat desa Damar Condong yakni, apabila antara kedua belah pihak bersepakat untuk melakukan kerjasama dalam mawah sapi, maka shahibul maal akan memberikan modal berupa sapi bukan berupa dengan uang tunai, namun juga tidak dijelaskan harga sapi tersebut secara spesifik pada saat awal akad melakukan perjanjian. Setelah sapi tersebut diserahkan kepada mudharib akan merawat sapi tersebut sesuai dengan tanggung jawab yang telah dilimpahkan kepadanya dari mulai makanan hingga kesehatan sapi tersebut, kemudia hasil dari perkembangbiakan dari sapi yang dimawahkan kepada mudharib akan dibagi rata antara shahibul maal dan mudharib. Namun, ketika sapi yang menjadi modal awal yang diberikan oleh shahibul maal atau bagian yang didapat shahibul maal hilang maka mudharib wajib mengganti sepenuhnya walaupun sapi tersebut hilang bukan disebabkan kelalaian ataupun kesengajaan mudharib.

2. Ditinjau dari pembiayaan mudharabah maka mekanisme mawah sapi di desa Damar Condong ditinjau dari pembiayaan mudharabah tidak dapat dilakukan karena bertentangan dengan teori pembiayaan mudharabah. Yakni pada mekanisme mawah sapi yang dilakukan oleh masyarakat desa Damar Condong shahibul maal tidak mempercayakan sepenuhnya modal kepada mudharib. Bahkan mudharib juga diharuskan mengganti rugi apabila sapi tersebut gagal dirawat atau hilang ditangan mudharib. Mekanisme Ini Juga Tidak Sesuai Dengan Fatwa DSN-MUI 07/DSN-MUI/ 2000 Tentang Pembiayaan Mudharabah (Qiradh) dimana didalamnya memuat bahwa yang berhak mengganti rugi adalah shahibul maal jika mudharib menjalankan kontribusi kerja sesuai kesepakatan bukan dikarenakan kelalaian.

\section{Saran}

${ }^{38}$ Akhmad Farroh Hasan, Fiqh Muamalah Dari Klasik Hingga Kontemporer (Teori dan Praktik), ..., h. 
1. Untuk meningkatkan pengetahuan bagi para mahasiswa atau mahasiswi khusunya prodi hukum ekonomi syariah tentang Pembiayaan mudharabah.

2. Untuk menambahkan wawasan masyarakat desa Damar Condong tentang mekanisme mawah sapi yang sesuai dengan hukum syara' agar tidak lagi menimbulkan mudharat.

3. Untuk menambahkan pengetahuan kepada para pihak yang melakukan mekanisme mawah sapi.

4. Tokoh masyarakat setempat khususnya Pemuka agama diharapkan dapat memberikan pengarahan atau informasi kepada masyarakat mengenai hukum pembiayaan mudharabah dalam islam dan hukum bermuamalat

\section{DAFTAR PUSTAKA}

A. Karim, Adiwarman. 2004. Bank Islam Analisis Fiqh dan Keuangan, Jakarta: Raja Grafindo Perdasa

Sudiarti, Sri. 2018. Fiqh Muamalah Kontemporer, Medan: FEBI UIN-SU Press

Farroh Hasan, Akhmad. 2018. Fiqh Muamalah Dari Klasik Hingga Kontemporer (Teori dan Praktik), Malang: UIN-Maliki Press

Fatwa DSN-MUI No.07/DSN-MUI/IV/2000 Tentang Pembiayaan Mudharabah

Sabiq, Sayyid. 2009. Fiqh Sunnah, jilid 4,Terj. Mujahidin Muhayan, Jakarta: Pena Pundi Aksara

Rahman, Afjalur . 2002. Doktrin Ekonomi Islam, Yogyakarta: Dhana Bakti Prima Yasa

Departemen Agama RI. 2007. Al-qur'anulkarim, Syaamil International

Sa'diyah, Mahmudatus. 2013. Mudharabah Dalam Fiqih Dan Perbankan Syari'ah,Volume 1, No.2

Rivai, Veithzal. 2008. Islamic Financial Manajgement, Jakarta: PT. Raja Grafindo Persada Press

Mansur. 2009. Seluk Beluk Ekonomi Islam, Salatiga: STAIN Salatiga

Syafi'i Antonio, Muhammad. 2001. Bank Syariah dari teori ke praktik, Jakarta: Gema Insani

Wardhi Muslihc, Ahmad. 2010. Fiqih Muamalah, Jakarata: Amzah

Asmuni, A.Rahmad. 2007. Ilmu Fiqh 3,Jakarta: Direktorat pemberdayaan wakaf Direktorat Jendral bimbingan masyarakat islam

Mawardi, Al. al-Hawi al-Kabir, Beirut: Darr al FikrGrafindo Persada

Soekanto, Soerjono \& Sri Mamudji. 1985. Penelitian Hukum Normative Suatu Tinjauan

Singkat, Jakarta: Raja 
J. Moelong, Lexy. 2008. Metodologi Penelitian Kualitatif, Bandung: PT. Remaja Rosdakaya

Bungin, Burhan. 2005. Metodologi Penelitian Sosial: Fromat 2 Kuantitatif dan Kualitatif, Surabaya: Airlangga University Press

Bungin, Burhan. 2007. Penelitian Kualitatif, Jakarta: Kencana 